\title{
NEGATIVE PERSONALITY TRAITS AND SELF-MONITORING AMONG HIGH SCHOOL TEACHERS
}

\author{
Ludmila Kalinnikova $^{1,2}$, Jelena Saplavska ${ }^{2}$, Aleksey Zavodilov ${ }^{1}$, Olga Rimkus ${ }^{2}$ \\ ",Psy Technology" LLC , Latvia; ${ }^{2}$ Baltic International Academy, Latvia \\ kalin.1@inbox.lv, lena.sapl@inbox.lv, aleksejs_zavodilovs@inbox.lv,novella_olga@mail.ru
}

\begin{abstract}
Within the communicative competence of a high school teacher, there are distinguished such skills as an ability to engage pupils in communication and make a favourable impression (self-presentation skill). High school teachers have to be able to demonstrate attractive features of own personality, show themselves as successful professionals. Thus, the requirement to create a positive impression of oneself, to have developed empathy and a high level of self-monitoring is emphasized. As a result of the research, a protective-nature change in the behaviour of middle-aged teachers has been revealed. It is noted that these manifestations in many respects resemble descriptions of the manifestation of negative personality traits included in the construct of the "Dark Triad". In this study, a theoretical analysis of the current understanding of the concepts of the "Dark Triad" and self-monitoring is provided, as well as an empirical study of the "Dark Triad" negative personality traits relation to self-monitoring among high school teachers. The examined variables refer to personality constructs. The study revealed a statistically significant correlation between self-monitoring and negative personality traits among high school teachers, which is explained theoretically by the manifestations of the characteristic features of the components of negative traits, including high self-monitoring level. Statistically significant correlations between machiavellianism and self-monitoring, as well as between narcissism, psychopathy, and self-monitoring were revealed. The study reveals a tendency to high levels of expression of all three "Dark Triad" personality traits as well as of self-monitoring, which is explained by the age peculiarities and specifics of high school teachers' professional activity.
\end{abstract}

Keywords: self-monitoring, the "Dark Triad", machiavellianism, narcissism, psychopathy.

\section{Introduction}

The personality of a teacher has traditionally been examined within the psychology of features framework. At the same time, the main attention of research is directed either to the identification of professionally important qualities of a teacher [1-2] or to the personality investigation within the 5Factor Model of Personality [3-4]. It can be noted that in most of the research only positive traits of a teacher's personality and their connection to various aspects of the professional activity have been described, which does not allow to explain the ambiguity of their behaviour in various professional situations, as well as the effectiveness of their professional activity. In studies, little attention has been paid to negative personality traits [5], which can become more pronounced in middle age and upon increasing work experience [6], as well as a result of emotional and intellectual overload due to a decrease in self-regulation.

Among the professionally important qualities of a teacher are specifically distinguished positive features: tolerance, empathy, communicative, openness [2]. These qualities are associated with the effectiveness of teaching and communication. Teachers demonstrating empathy in the educational process are more disposed to provide support and interact with pupils and colleagues. Within the communicative competence of a teacher, the ability to create circumstances promoting communication with pupils, to make a favourable impression (self-presentation skills), to reflect, adequately perceive peculiarities of other peoples' personalities, to predict the development vector of intersubject relations, and adequately use the mechanisms of communicative impact has been described [7]. Research shows that the lack of communicative skills of a teacher suppresses the initiative of pupils, leads to the restriction of their freedom, suppresses cognitive activity, and impedes the learning outcomes [8]. It is stated that a teacher is required to be able to demonstrate attractive features of their personality, to show themselves as successful professionals. Thus, the need to create a positive impression of oneself, to have developed empathy and a high level of self-monitoring are emphasized. At the same time, there are studies describing the effect of a teacher's negative personality traits on their professional behaviour. It has been revealed [5] that teachers with a high level of machiavellianism are more adapted to rules accepted at a modern high school and are oriented towards the requirements of their administration, whereas teachers with an average level are more oriented towards quality teaching their subjects. Research has shown [9] that the narcissism of a teacher is manifested in a decline in the quality of teaching and educational process organization, which leads to a drop in academic 
motivation among pupils. Following the description [10] of productive and unproductive forms of narcissism, it can be assumed that, on the one hand, teachers can be high achievers aiming for higher ratings and positions, trying to create a favourable impression among pupils, parents and administration, on the other hand, they can exaggerate their merit or manipulate pupils, using them to their advantage. Manifestations of authoritarianism, detachment from pupils, arrogance, intolerance to criticism and hostility are more often investigated in studies on professional disadaptation of teachers, whereas this behaviour is described as "protective". Studies on manifestations of the non-clinical form of psychopathy among high school teachers were not found.

Thus, the analysis of the conducted studies allows us to state that the attention of researchers is focused on investigating the influence of individual negative traits of a teacher's personality on their professional activity. Studies on the manifestations of a single complex of the "Dark Triad" negative personality traits among teachers have not been found [11-14]. Theoretical works on this issue indicate [13] that manifestations of subclinical personality traits (machiavellianism, narcissism, and psychopathy) are in many respects similar, which makes it possible to treat the "Dark Triad" as a multidimensional construct. The conclusion is made on the basis of the correlation analysis of the relationships between the variables. Some authors [11] note that the high scores on the "Dark Triad" components indicate the ability to deftly manoeuvre in social situations, whilst pursuing own goals by manipulating and exploiting other people. To achieve this, the individuals require certain skills to control and manage social perceptions and own behaviour ("social performance"). A review of the studies on the links among the "Dark Triad" components [13] demonstrated that a significant connection is almost always found.

Traditionally, the "Dark Triad", as a construct, is described as a set of negative personality traits in terms of public morality and norms of interpersonal relationships [15]. Most researchers suggest that the features of the "Dark Triad" combine a low level of empathy, tendencies to lie and manipulate, the desire to make a favourable impression. At the same time, it is noted that the manifestation of the components of the "Dark Triad" is ambiguous [11]. Under certain circumstances, these features can be manifested effectively [16-17]. It was revealed that the nature of manifestations of these features may depend on the level of the feature development, as well as on the content of the work being performed. The authors of recent research [16] note that the issue of situational factors effect on the individual manifestation of these personality traits in the work process is understudied.

Some authors [18] suggest that the features of the "Dark Triad" are positively linked to the factors of self-monitoring: perceptivity, control of the impression produced on other people, the protective variability of behaviour.

As noted in previous research [19-20], the modern understanding of the self-monitoring concept is associated with the description of the development level of particular personal traits that allows to regard it as an inhomogeneous construct. The authors consider self-monitoring as a person's ability and aspiration to control one's behaviour and the impression produced through self-observation and observation of the reaction of other people. It has been revealed that self-monitoring is manifested as a result of the desire of an individual to receive rewards, their focus on achievements, or as defensive behaviour [21]. Most authors describe the manipulative "social chameleon" behaviour as the dominant of an individual social behaviour, which potentially associates self-monitoring with the features of the "Dark Triad". Research [22] revealed a positive link between self-monitoring and such the "Dark Triad" components as machiavellianism, narcissism, and psychopathy. In the study of the correlation of the "Dark Triad" components and self-monitoring [18] it was revealed that the individuals demonstrating the "Dark Triad" components in their behaviours have the ability to track impressions made on other people and adjust their behaviour to the expectations of others. It was found that narcissism is associated with the adaptive form of self-monitoring, machiavellianism with the protective form, and psychopathy with both. It is noted [17] that the high level of intellect of a psychopathic person allows compensating for the manifestations of negative personality traits.

The connections revealed between the negative personality traits of the "Dark Triad" and selfmonitoring can serve as a basis for explaining the variability in the manifestation of these traits in professional activity. Despite the fact that there is no much research on links between self-monitoring and negative personality traits of high school teachers, it can be assumed that this relationship exists, manifested in defensive forms of behaviour. This relationship can be justified by the specifics of the 
activity of a high school teacher, in which the need to follow regulatory requirements, standards, and behavioural patterns is related to maintaining professional status. Self-monitoring among teachers is manifested in direct or indirect self-presentation aimed at pupils, colleagues, parents, administration in the process of implementation and organization of a teaching process while conducting and presenting results of their work. The impression of self is regulated on the basis of observation and feedback to increase own rating and achieve the goals set. The research question and the aim of this study are formulated based on the theoretical positions of the "Dark Triad" model [13], as well as theoretical statements about the nature and essence of self-monitoring [20]. The basis of this study is the consideration of the "Dark Triad" and self-monitoring as personality traits.

The aim of the study: a theoretical analysis of the current understanding of the concepts of the "Dark Triad" and of self-monitoring, and an empirical investigation of the "Dark Triad" negative personality traits relation to self-monitoring among high school teachers.

Research question: Whether there is a connection between negative personality traits and selfmonitoring among high school teachers?

\section{Materials and method}

Study participants

The study involved teachers $N=42$ participants aged $25-49$ years $(M=43.38, S D=7.30)$. All participants were female. The sample is homogeneous. The age distribution of the participants was not normally distributed: for skewness $.42(S E S=.37)$ and kurtosis $.30(S E K=.72) .50 \%$ of the participants are not older than $M d n=44.5$ years old.

Methods of the study

- Dark Triad of Personality - D3-Short (Paulhus) [23], in the adaptation of Yegorova and colleagues [24];

- 18-Item Self-Monitoring Scale (Snyder \& Gangestad) [25], in the adaptation of Polezhaeva [26].

\section{Results and discussion}

\section{Descriptive Statistics}

Descriptive statistics revealed the non-normal distribution of the empirical data; therefore, the non-parametrical criteria were implemented for further analysis. The Spearman rank correlation coefficient was implemented to study the links between negative personality traits and self-monitoring among high school teachers. The analysis of nominative data ( $\chi 2$-Pearson test) was carried out. Data processing was run by SPSS 20.0 computer software. The mathematical tests of the study were chosen to answer the research questions defined above.

\section{Correlation analysis}

As a result of the correlation analysis, statistically significant connections between selfmonitoring and the "Dark Triad" negative personality traits were revealed, as well as correlation links between the features that constitute the "Dark Triad" - machiavellianism, narcissism and psychopathy (Fig. 1).

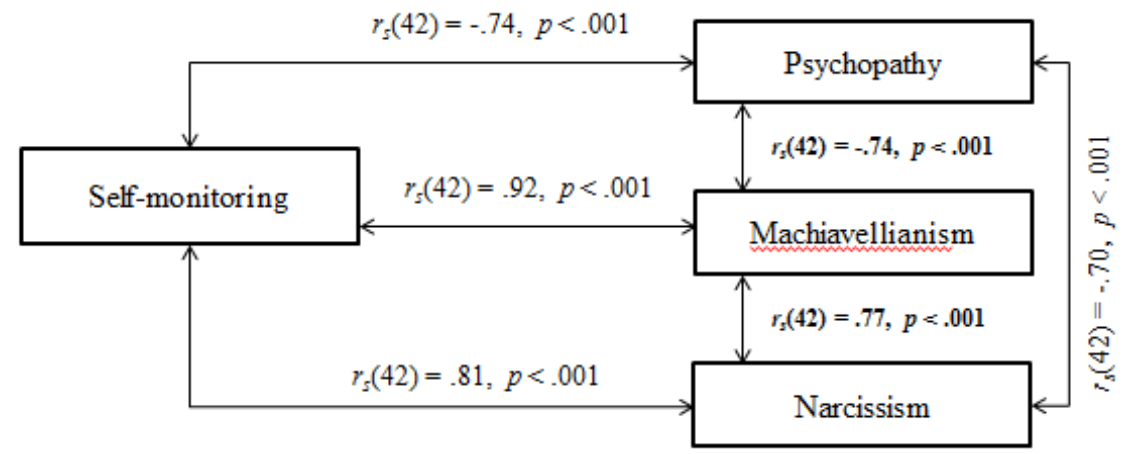

Fig. 1. Correlations revealed between variables 
It was found that machiavellianism and narcissism $\left(r_{s}(42)=0.77, p<0.001\right)$ positively correlate with each other, and psychopathy and machiavellianism $\left(\left(r_{s}(42)=-0.74, p<0.001\right)\right.$, and psychopathy and narcissism $\left(r_{s}(42)=-0.70, p<0.001\right)$ correlate negatively. A positive correlation was revealed between self-monitoring and indicators of machiavellianism $\left(r_{s}(42)=0.92, p<0.001\right)$ and indicators of narcissism $\left(r_{s}(42)=0.81, p<0.001\right)$. A negative correlation was revealed between self-monitoring and indicators of psychopathy $\left(r_{s}(42)=-0.74, p<0.001\right)$.

The $\chi^{2}$ chi-square test was implemented to distinguish, whether distributions of subgroups of nominal variables differ significantly from each other (empirical data used for analysis and comparison can be available upon request by to author's e-mail kalin.1@inbox.lv). For this purpose, self-monitoring and the indicators of the "Dark Triad" were divided into low, medium and high levels. The data were sorted based on the percentile values of each. As a result of all the variables division into levels, the cross tabulation frequency tables were obtained and the diagram representing the distribution of the obtained levels constructed based on the data from the table (Fig. 2).

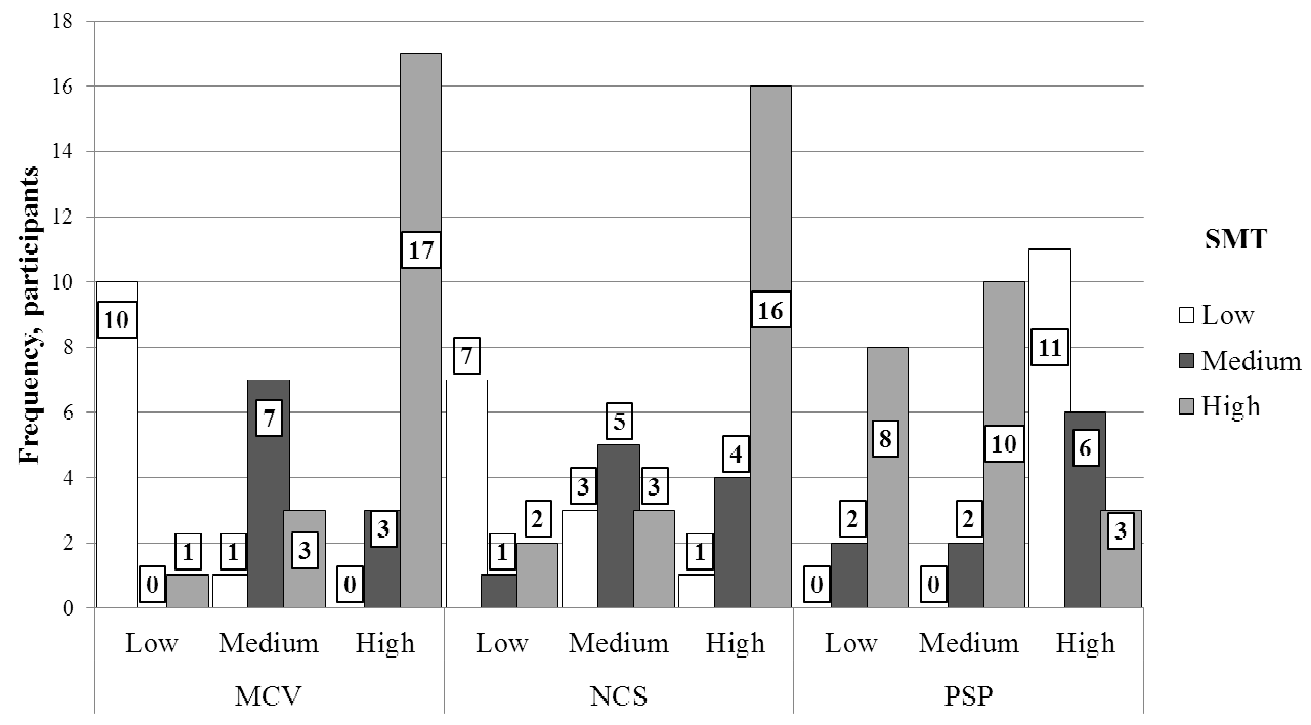

Fig. 2. Distribution of indicators of self-monitoring and "Dark Triad" negative personality traits

The analysis of the differences in distributions according to the $\chi^{2}$ chi-square test demonstrated the most significant results (Fig.2): "Machiavellianism (MCV) - Self-monitoring (SMT)" $\left(\chi^{2}(4, N=42)=\right.$ 44.38, $p<0.001)$; "Narcissism (NCS) - Self-monitoring (SMT)" $\left(\chi^{2}(4, N=42)=20.0, p<0.001\right.$; "Psychopathy (PSP) - Self-monitoring (SMT)" $\left(\chi^{2}(4, N=42)=22.11, p<0.001\right.$.

The analysis of the obtained distribution allows identifying the trends distinctive for this sample. Thus, a high level of self-monitoring prevails among participants with high levels of machiavellianism and narcissism, as well as low and medium psychopathy levels. A low level of self-monitoring prevails among participants with a high level of psychopathy.

\section{Discussion}

As a result of the research, a positive confirmation of the research question "Whether there is a connection between negative personality traits and self-monitoring among high school teachers?" was obtained. This result corresponds with the assumptions that the "Dark Triad" features correlate with a high level of self-monitoring [18], as well as the theoretical explanation of the manifestations of the "Dark Triad" components' distinctive features including the high level of self-monitoring [14; 27-28]. This link can be explained by the similarities in the manifestations of the "Dark Triad" components and self-monitoring. Individuals with established features of the "Dark Triad" have the ability to track impressions made on other people and adjust their behaviour according to the expectations of others. In theoretical studies, it is described that people, who have a high level of self-monitoring, respond quickly and easily to the requirements of socially conditioned situations and respond to signs produced by partners within situations of interpersonal relationships. This ability is one of the professionally important qualities of a teacher. 
The relationships between the components of the "Dark Triad" construct revealed in the current study agree with the results of earlier research [11-12].

Strong positive statistically significant links between the indicators of machiavellianism and selfmonitoring, as well as between the indicators of narcissism and self-monitoring were revealed.

The data obtained are consistent with the theoretical explanations of the behaviour of people with a high level of machiavellianism, which is associated with self-monitoring, i.e. the ability to track the impression made on others and adjust it according to the preferences of people around [26-27; 29], thus, implementing various ways of their goal achievement. The obtained correlation between the indicators of narcissism and self-monitoring corresponds to the results of the earlier study [29], which revealed that narcissism is associated with the adaptive form of self-monitoring. A negative correlation with maximal statistical significance revealed between the parameters of psychopathy and selfmonitoring is consistent with the results of the study [18]. The indicated negative relationship between the variables can be explained by the high impulsivity and low anxiety levels typical for nonclinical psychopathy [30]. It is defensive behaviour with high self-monitoring that is associated with the desire to control the manifestations of high impulsiveness and adequately respond to the requirements of situations. This desire is related to teacher's professional work requirements.

Based on the frequency analysis, a statistically significant distribution of the study participants into groups in accordance with the level of the components of the "Dark Triad" and self-monitoring revealed. The results are consistent with studies demonstrating the presence of self-monitoring of different levels in the "Dark Triad's" components description.

The study found that in the group of teachers with a high level of machiavellianism, a high level of self-monitoring prevails. A high level of self-monitoring disguises the negative aspects of this feature. To maintain their status, individuals with an established machiavellianism quickly react to the changing situation, easily adopt suitable roles, despite their true attitude. The ability to manipulate allows making the right impression on the right people, which facilitates avoiding conflict situations with administration, colleagues, and pupils. The high self-monitoring level allows concealing situationally manifested traits of machiavellianism in case of stress and instability [31]. In this instance, it performs a protective function.

The study revealed that in the group of teachers with a low machiavellianism level a low level of self-monitoring prevails. It can be assumed that this group includes teachers, who do not have the capacity and the desire to change their behaviour depending on the situation. Because of their excessive orientation to their principles and views, they can be unnecessarily principled and straightforward, which leads to resentment on behalf of colleagues, conflicts with the administration and pupils. It can be assumed that the behaviour of such teachers is stable and predictable, depending on their state and mood. Usually, there is a definite and unchangeable opinion among pupils, colleagues, and administration about them [32]. The study found that in the group of teachers with a high narcissism level a high level of self-monitoring prevails. High self-monitoring is a part of the narcissism manifestations. On the other hand, well-developed self-monitoring helps a teacher with pronounced features of narcissism behave in accordance with the situation. The study revealed that in the group of teachers with a low narcissism level a low level of self-monitoring prevails. Teachers belonging to this group can be very responsible, obligatory and constant in their relations. It is not always possible for them to change behaviour in accordance with the situation, which can lead to negative attitude on behalf of pupils [20]. The study revealed that in the group of teachers with a high psychopathy level a low level of self-monitoring prevails. Often, such teachers may be dissatisfied with life, thus, overall unhappy [14]. The study found that in the group of teachers with a low level of psychopathy a high level of self-monitoring prevails. The manifestations of this combination can be similar to the behaviour of individuals with low-level indicators on all scales of the "Dark Triad". It can be assumed that the teachers of this group can be highly anxious, over-responsible people, pedantic and rigid. These qualities make it possible for the teachers to perform their professional duties well, but they also may have difficulties in manifesting their professionalism in communication.

Certain limitations of this study were, on the one hand, ambiguity in the definition of the selfmonitoring construct. On the other hand, the fact that the interpretation of the results of the selfmonitoring questionnaire has not been yet developed. 


\section{Conclusions}

1. The revealed trend typical for the sample is that almost half of the participants have a high level of expression of all the components of the "Dark Triad" and self-monitoring, which can be explained by the age of the respondents being studied as well as peculiarities of the professional activity of the teachers.

2. Links between all components of the "Dark Triad" construct were revealed.

3. Strong positive statistically significant links between the indicators of machiavellianism, narcissism, and self-monitoring were revealed, which is explained by the behavioural similarities of people with a certain level of features of machiavellianism and narcissism, and people with different levels of self-monitoring.

4. A revealed strong negative relationship with maximal statistical significance between the indicators of psychopathy and self-monitoring is explained by the peculiarities of the psychopathy traits manifestation associated with difficulties to control and regulate own behaviour.

5. Based on the frequency analysis, a statistically significant distribution of the study participants into groups in accordance with the level of the components of the "Dark Triad" and selfmonitoring revealed. This is explained by descriptions of different levels of self-monitoring across the "Dark Triad" components.

6. A further expanded study of the problem on a larger sample is required.

\section{References}

[1] Getzels J.W., Jackson P.W. The teacher's personality and characteristics. In N. L. Gage (Ed.), Handbook of research on teaching, Chicago, IL: Rand McNally, 1963, pp. 506-582.

[2] Skrynnik N.E. Professional-important qualities of a high school teacher/Proceedings of the International scientific and practical Internet-conference "Teacher of higher education in the twenty-first century", 2014. [online] [08.02.2018]. Available at: http://www.t21.rgups.ru/.

[3] Cutchin G.C. Relationships between the big five personality factors and performance criteria for in-service high school teachers. Purdue University, 1998. [online] [08.02.2018]. Available at: https://docs.lib.purdue.edu/dissertations/AAI9900173/.

[4] Buela S., Mamman J.C. Relationship between Personality and Teacher Effectiveness of High School Teachers. The International Journal of Indian Psychology, vol. 3(1), 2015. DIP: C03116V3I12015. [online] [10.02.2018]. Available at: oaji.net/articles/2015/11701449511142.pdf.

[5] Каяшева О., Ханова 3. Представления о профессиональной успешности у преподавателей высших учебных заведений с разным уровнем макиавеллизма (View of professional success of the teachers of higher educational institutions with different levels of Machiavellianism). Kazan Pedagogical Journal, vol. 6(119), 2016, pp. 160-165. (In Russian). [online] [08.02.2018]. Available at: https://elibrary.ru/item.asp?id=27719598.

[6] Ильин Е.П. Психология помощи. Альтруизм, эгоизм, эмпатия (Psychology of help. Altruism, egoism, empathy). St. Petersburg, Publ. House: "Peter", 2013, pp. 246-249. (In Russian).

[7] Кириченко С. Профессионально-коммуникативные умения педагога (Professional and communicative abilities of a teacher), 2013. (In Russian). [online] [08.02.2018]. Available at: http://nsportal.ru/.

[8] Понутриева С. Коммуникативные умения учителя как условия активизации познавательной деятельности учащихся (Communicative abilities of a teacher as a prerequisite of cognitive activity activation among students). Kaluga State Pedagogikal University, 1997. (In Russian). Available at: http://childpsy.ru/dissertations/id/19457.php.

[9] Арский А. Нарциссизм в высшей школе. Проблемы и тенденции (Narcissism at the higher school. Problems and tendencies). Journal "World of modern science", vol. 6(34), 2015, pp. 86-89. (In Russian). [online] [08.02.2018]. Available at: http://elib.fa.ru/art2015/bv4731.pdf.

[10] Bursten B. Some Narcissistic Personality Types. IJAP, vol. 54, 1973, pp. 287-300.

[11] Paulhus D.L., Williams K.M. The Dark Triad of personality: Narcissism, Machiavellianism, and psychopathy. Journal of Research in Personality, vol. 36, 6(6), 2002, pp. 556-563.

[12] Jonason P.K., Li N.P., Teicher E.A. Who is James Bond? The Dark Triad as an agentic social style. Individual Differences Research, vol. 8(2), 2010, pp. 111-120. 
[13]Furnham A., Richards S.C., Paulhus D.L. The Dark Triad of Personality: a 10 year review. Social and Personality Psychology Compass, vol. 7(3), 2013, pp.199-216.

[14] Егорова М., Ситникова М. Темная Триада (The Dark Triad). Psychological Research Journal, vol. 7(38), 2014. (In Russian). [online] [08.02.2018]. Available at: http://psystudy.ru/index.php/num/2014v7n38/1071-egorova38.html.

[15]Корнилова Т., Корнилов С., Чумакова М., Талмач М. Методика диагностики личностных черт Темной Триады: апробация опросника Темная Дюжина (The Dark Triad personality traits measure: Approbation of the Dirty Dozen questionnaire). Journal of Psychology, vol. 36(2), 2015, pp. 99-112. (In Russian). [online] [08.02.2018]. Available at: https://www.researchgate.net/publication/288429959_The_Dark_Triad_personality_traits_measur e_Approbation_of_the_Dirty_Dozen_questionnaire.

[16] Spain S.M., Harms P.D., Lebreton J.M. The dark side of personality at work. Journal of Organizational Behavior, vol. 35, 2014, pp. 41-60. [online] [08.02.2018]. Available at: http://digitalcommons.unl.edu/managementfacpub/99.

[17] Spurk D., Keller A.C., Hirschi A. Do Bad Guys Get Ahead or Fall Behind? Relationships of the Dark Triad of Personality with Objective and Subjective Career Success. Social Psychological and Personality Science, vol. 7(2), 2016, pp. 113-121.

[18] Rauthmann J.F., Franzens L. Acquisitive or protective self-presentation of dark personalities? Associations among the Dark Triad and self-monitoring. Personality and Individual Differences, vol. 51(4), 2011, pp. 502-508.

[19] Snyder M. Self-monitoring of expressive behavior. Journal of Personality and Social Psychology, vol. 30, 1974, pp. 526-537. [online] [08.02.2018]. Available at: http://garfield.library.upenn.edu/classics1984/A1984SA89100001.pdf.

[20] Gangestad S., Snyder M. Self-Monitoring: Appraisal and Reappraisal. Psychological Bulletin, vol. 126(4), 2000, pp. 530-555.

[21] Arkin R.M. Self-presentational styles. In J. T. Tedeschi (Ed.), Impression management theory and social psychological research. New York: Academic Press, 1981, pp. 311-333.

[22] Kowalski C.M., Rogoza R., Vernonc F.A., Schermerd J.A. The Dark Triad and the selfpresentation variables of socially desirable responding and self-monitoring. Personality and Individual Differences, vol. 120(1), 2018, pp. 234-237.

[23] Paulhus D.L. Dark Triad of Personality (D3-Short). Measurement Instrument Database for the Social Science, 2013. [online] [08.02.2018]. Available at: www.midss.org/sites/default/files/d3.pdf.

[24]Егорова М., Ситникова М., Паршикова О. Адаптация короткого опросника Темной триады (Adaptation of the Dark Triad). Journal of Personality and Social Psychology, vol. 8(43), 2015. (In Russian). [online] [06.02.2018]. Available at: http://psystudy.ru/num/2015v8n43/1181egorova43.html.

[25] Snyder M., Gangestad S. On the Nature of Self-Monitoring: Matters of Assessment, Matters of Validity. Journal of Personality and Social Psychology, vol. 51(1), 1986, pp. 125-139.

[26] Полежаева Е. Место самомониторинга в структуре личностных характеристик (Place of Self-monitoring in the structure of personality characteristics), 2009. (In Russian). [online] [06.02.2018]. Available at: http://www.dissercat.com/content/mesto-samomonitoringa-vstrukture-lichnostnykh-kharakteristik.

[27] Abell L., Brewer G. Machiavellianism, self-monitoring, self-promotion and relational aggression on Facebook. Journal of Computers in Human Behavior, vol. 36, 2014, pp. 258-262.

[28] Campbell W.K., Hoffman D.J., Campbell S.M., Marchisio, G. Narcissism in organizational contexts. Human Resource Management Review, vol. 21(4), 2011, pp. 268-284.

[29] Ickes W., Reidhead S., Patterson M. Machiavellianism and Self- monitoring: as different as "me" and "you". Journal of Social Cognition, vol. 4(1), 1986, pp. 58-74.

[30] Lilienfeld S.O., Andrews B.P. Development and preliminary validation of a self-report measure of psychopathic personality traits in noncriminal populations. Journal of Personality Assessment, vol. 66, 1996, pp. 488-524.

[31] Ларина А. Подходы, установки и перспективыв исследовании макиавеллизм (Approaches, Mindsets and Prospects in Machiavellianism Research). Journal of Psychology Issues, vol. 3, 2010, pp.75-83. (In Russian).

[32] Организационное поведение (Organizational behaviour). Под ред. Латфуллина Г. и Громовой O.. St. Petersburg. Publ. House "Peter", 2015, 464 p. (In Russian). 